\title{
Globalization and Ethnic Diversity in Western Newspaper Coverage of Literary Authors: Comparing Developments in France, Germany, the Netherlands, and the United States, 1955 to 2005
}

\author{
Pauwke Berkers, Susanne Janssen and Marc Verboord
}

\section{Erasmus University Rotterdam}

In contrast to most studies on cultural globalization, this article examines the dynamics of crosscultural exchange between and within (western) nation-states. Through content analysis, we study the extent and composition of newspaper coverage given to literary authors of non-western ethnic origin both foreign and domestic - in four nations over fifty years. Our analysis reveals, among other things, that newspaper attention to ethnic minority authors appears related to various features of a nation's ethnic minority population, the extent that a given national literary field is receptive to ethnic diversity, and the relative position of that nation in the literary world-system.

Key words: cultural globalization; ethnic minorities; literature; journalism; comparative research

\section{INTRODUCTION}

Globalization is one of the most popular albeit ill-defined topics in the social sciences (Fiss \& Hirsch, 2005; Hargittai \& Centeno, 2001). Combining common elements, Guillén (2001, p. 236) describes it as "a process leading to greater interdependence and mutual awareness (reflexivity) among economic, political, and social units in the world, and among actors in general.” However, scholars of cultural globalization generally have a narrower focus, studying the transnational diffusion of western popular culture (Crane, 2002; Kaufman \& Patterson, 2005). Dominant theoretical perspectives either emphasize cultural homogenization through the imperialism of western multinationals or the capacities of local actors to transform global cultural products into hybrid cultural forms (Kraidy, 2002; Lizardo, 2008). As a result, cultural globalization studies have largely neglected: (a) the increasing diffusion of cultural artifacts of non-western origin in the western world; (b) the level of institutional recognition of such artifacts within western nation-states; and (c) the role of international migration in this context.

We address these issues through a comparative analysis of the extent and composition of newspaper coverage given to literary authors of non-western ethnic origin ${ }^{1}$ in France, Germany, the Netherlands, and the United States between 1955 and 2005. Postcolonial literary scholars signal a substantial "contra-flow" from the "rest" to the West, resulting in an ethnically more diverse supply of literary works in western countries (Huggan, 2001). Moreover, international migration - one of the most omnipresent forms of globalization

\footnotetext{
*Authors' Note: Corresponding Author:

Pauwke Berkers, Erasmus University Rotterdam, Room L2-007, P.O. Box 1738, Rotterdam NL-3000 DR, Netherlands. Email: berkers@eshcc.eur.nl. This research was supported by the Netherlands Organization for Scientific Research as part of the VICI-project Cultural Classifications in Transition (NWO- project 277-45-001). We want to thank Sarah Corse, Tim Dowd, Gisèle Sapiro, and the anonymous reviewers of American Behavioral Scientist for their valuable comments on earlier drafts of this article and Annemarie Kersten for research assistance.

${ }^{1}$ See the Data and Methods section for the rationales underlying our usage of this "meta-category."
} 
(Held, McGrew, Goldblatt, \& Perraton, 1999) - has given rise to ethnic minority authors in these countries, leading to greater awareness of the ethnic other from within western nationstates. We analyze the dynamics of cross-cultural literary exchange not only between but also within nation-states, considering western newspaper coverage of both foreign literary authors of non-western ethnic origin and domestic ethnic minority authors.

Literary coverage in western elite newspapers provides an excellent case for studying the institutional recognition of authors with a non-western background. These newspapers select, shape and frame what is considered socially and culturally relevant (Ferree, Gamson, Gerhards \& Rucht, 2002; Shoemaker \& Reese, 1996). They also play a key role in the legitimation and consecration of cultural artifacts, as their selections and judgments channel and shape subsequent perception and valuation by audiences and other actors in the cultural field (Bourdieu, 1993; van Rees, 1983). Through a content analysis of the newspaper coverage given to non-western writers in various western countries, we may thus assess the extent to which increased awareness of the ethnic "other" has been transformed into institutional recognition in these societies. We include France, Germany, the Netherlands and the U.S. in our study to compare the journalistic attention to non-western authors across traditional nations of immigration (the U.S.), former colonial powers (France, the Netherlands), and guest worker recruitment countries (Germany).

Institutional recognition of domestic (Berkers, 2009a; Duell, 2000) and foreign authors of non-western ethnic origin (Griswold, 1987) appears to result in part from similar macro-structural processes (e.g., international migration). However, the latter category of authors often have already received some literary recognition in their home country and/or in one of the major literary centers (Casanova, 2004; Malingret, 2002), while the valuation of domestic ethnic minority authors seems more often linked to questions of acculturation and their relationship to the national literary field. Before presenting the design and findings of our analysis, we consider various macro-structural and field-level factors that may influence the coverage given to both categories of authors.

\section{THEORETICAL BACKGROUND}

\section{Coverage of Domestic Ethnic Minority Authors}

Newspaper coverage given to ethnic minority authors in the studied countries may be affected by various characteristics of each country's ethnic minority population (size, language skills and level of education) and the degree of field-level recognition of ethnic minority authors.

\section{Ethnic Minority Population, Language Skills and Level of Education}

In the absence of reliable, longitudinal data on the population of ethnic minority authors in each country - only impressionistic lists of ethnic minority authors exist - we first look at the size of each country's minority population (Table 1) because that possibly affects the presence of ethnic minority authors in each country. The French government does not distinguish between majorities and minorities and as such only collects data on the foreign population. The share of non-western foreigners is just over 3\% in $1999 .^{2}$ As longitudinal data on other non-western minority groups are unavailable, we use the Turkish minority as proxy for the non-western minority population in Germany. Turks are by far the largest ethnic minority group in Germany, representing 2-3\% of the population. In the United States, ethnoracial minorities account for about one fifth (1975) to one third (2005) of the population, which is a multiple of the share of non-western ethnic minorities in the Netherlands.

\footnotetext{
${ }^{2}$ Fetzer and Soper (2005) estimate that the share of non-western minorities is twice as large.
} 
Table 1: Background Characteristics Ethnic Minority Groups in France, Germany, the Netherlands, and the United States.

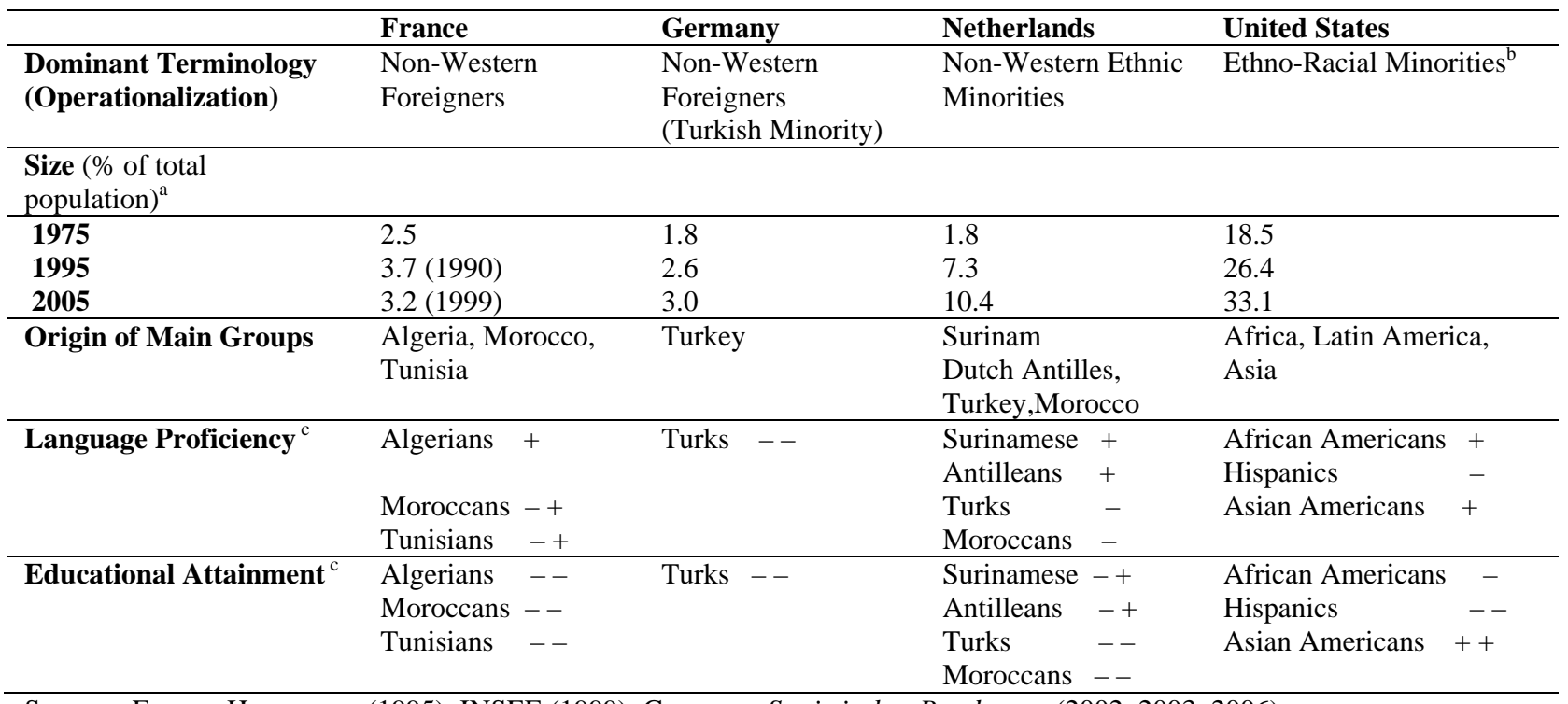

Sources: France: Hargreaves (1995), INSEE (1999); Germany: Statistisches Bundesamt (2002, 2003, 2006);

Netherlands: Centraal Bureau voor de Statistiek (2008) United States: U.S. Bureau of the Census (1981, 2000, 2007).

${ }^{\mathrm{a}}$ We did not include 1955 because no comparable data are available for that particular year.

${ }^{\mathrm{b}}$ People describing themselves as Black or African American, Hispanic or Latino, Asian or Pacific Islander and American Indian or Alaska Native.

c( $(--)=$ very low; $(-)=$ low; $(-+)=$ medium; $(+)=$ high; $(++)=$ very high (vis-a-vis other minority groups).

However, sheer numbers provide a crude indication of the presence of ethnic minority authors at best. The literary fields of Western societies are notoriously selective in terms of social background, level of schooling and language skills. Becoming a literary author - i.e., to become recognized as such by literary publishers and other relevant actors in the literary field - requires a substantial amount of "cultural” and "linguistic" capital (Bourdieu, 1993).

Members of the lower socio-economic strata are thus less likely to gain access to the literary field, and this holds a fortiori if they lack sufficient language skills and schooling.

In France, the Maghrebis - particularly the Algerian minority - have fairly good French language skills, but they are overrepresented in the lower social strata (Hargreaves 1995). The Turkish minority in Germany is generally far less proficient in German and has a lower level of education than other ethnic minority groups (Dustmann, 1994; Worbs, 2003). The language skills and educational attainment of immigrants (and their descendants) from the former Dutch colonies are not so far behind the Dutch majority, contrary to those of the Turkish and Moroccan minorities (Tesser, Merens \& Van Praag, 1999). Language homogeneity is seen as the foundation of American nationhood and identity, which has led ethnic minority groups to adapt the new language much faster than in other countries (Portes \& Rumbaut, 1996). However, ethno-racial groups differ strongly in English language proficiency; Hispanics lag behind other minority groups (Carliner, 2000). On average, they also have a lower educational background compared to other minority groups (Table 1)

\section{Institutional Recognition and the Literary Field}

In view of the above features of each country's ethnic minority population, the U.S. likely has the biggest population of ethnic minority authors and Germany the smallest, with in between positions for France and the Netherlands. However, the sheer presence of ethnic minority authors does not automatically lead to newspaper coverage of these authors. Such attention also depends on the power relations in a country's literary field (Bourdieu, 1993), where 
diverse groups propose, support and contest (legitimate) conceptions of literature and newcomers challenge established positions. The outcome of this struggle determines, among other things, which writers are granted institutional recognition. In the absence of an objective instrument for determining literary quality, journalistic critics tend to reproduce the selections of other experts in the literary field (Janssen, 1997; van Rees, 1983). Thus, the degree to which authoritative institutions in the literary field - academic literary criticism (canons), literary policy and literary prizes - devote attention to ethnic diversity appears a good predictor of the level of newspaper coverage of ethnic minority authors.

Ethnic diversity has been an important issue in the American literary field since the Civil Rights movement. The late 1960s witnessed the initiation of programs and departments in African American Studies, followed by other, albeit less successful "group studies" like Latino, Native American and Asian American Studies (Duell, 2000). Despite "countermobilization" efforts by conservative academic elites in the 1980s and 1990s, these canon wars advanced the recognition of ethnic minority authors (Bryson, 2005; Corse \& Griffin, 1997). Concomitantly, the representation of ethnic minority authors in literary anthologies and scholarly literary journals increased quite drastically (Berkers, 2009b). However, the National Endowment for the Arts' funding of ethnic minority authors has declined somewhat over time (Berkers, 2009a), while few ethnic minority writers have received a prestigious literary prize. ${ }^{3}$

The French idea of universalism suggests there is no need to challenge the literary canon: meritocracy and equality will ensure that every author - majority or minority - has the same chance of being canonized (Duell, 2000). Several France-based authors of non-western origin received the prestigious Prix Goncourt, ${ }^{4}$ but on the whole, the French literary field seems not very receptive to ethnic diversity. Some scholars suggest that these writers simply do not meet the high demands of French publishers and critics (Lay-Chenchabi, 2004). Others indicate that French publishers are not particularly interested in ethnic minority authors since - because of the universalist French tradition - they cannot use these authors' background as a selling point (e.g., Obbema, 2003).

German literature departments have been reluctant - if not resistant - toward multiculturalism and works by ethnic minority writers have not become part of the literary canon (Jankowsky, 1997). Ethnic minority authors are largely absent from German literary history books as well as literary journals (Berkers, 2009b). In early 2000, the German Literature Fund supported approximately 400 individual authors of whom only two ${ }^{5}$ were of Turkish descent (Berkers, 2009a). Both authors are also the only minority writers who won prestigious literary prizes (Rösch, 2006).

In the Netherlands, the literary canon was subjected to some debate, but no "war" was waged over it (Joosten, 2005). Since the late 1980s, the share of ethnic minority authors in literary history books increased slowly to about 4\% in 2006 (Berkers, 2009b). However, the Dutch Literature Fund specifically targets ethnic minority authors and has separate funds available for such authors. The share of ethnic minority writers supported by this fund increased from 1\% in 1970 to 7\% in 2005 (Berkers, 2009a). In recent years, several ethnic minority authors ${ }^{6}$ received prestigious national literary awards (T’Sjoen, 2004).

These data on receptiveness to ethnic diversity within each country's literary field suggest that ethnic minority authors are most likely to be featured in U.S. newspapers and least so in French and German newspapers, with an in-between position for the Netherlands.

\footnotetext{
3 Between 1955 and 2005, three ethnic minority writers wan the National Book Award - Alice Walker (1983), Charles Johnson (1990), Jin Ha (1999) - while seven ethnic minority writers received the Pulitzer Prize Fiction: N. Scott Momaday (1969), James Alan McPherson (1978), Alice Walker (1983), Toni Morrison (1988), Oscar Hijuelos (1990), Jhumpa Lahiri (2000), Edward P. Jones (2004).

${ }^{4}$ Tahar Ben Jelloun (1987), Amin Malouf (1993), Patrick Chamoiseau (1995).

${ }^{5}$ Emine Sevgi Özadamar and Feridun Zaimoglu.

${ }^{6}$ Kader Abdolah, Abdelkader Benali, Hafid Bouazza, and Mustafa Stitou.
} 


\section{Coverage of Foreign Authors of Non-Western Ethnic Origin}

The level and composition of the newspaper coverage given to foreign literary authors of nonwestern ethnic origin can be expected to vary across countries according to their position in the literary world-system and their geo-linguistic ties with non-western countries.

\section{Literary World-System}

In the wake of cultural globalization, national literary fields have become embedded in transnational systems of exchange, influence, and competition. The result has been a "literary world-system" (Heilbron, 1999), which involves an implicit classification of countries according to the perceived importance of their literary production. A country's centrality in this literary world-system will likely affect the level of newspaper coverage given to foreign authors of non-western origin (Janssen, 2009): the more central a country's position, the more attention its newspapers will devote to domestic - instead of foreign (non-western) - authors; and the more attention foreign newspapers will pay to this country's (ethnic minority) writers or to foreign authors (of non-western origin) who reside in this country. Newspapers in less central countries are more likely to devote attention to foreign authors based in central countries, including those of non-western origin.

In 1955, the United States already had a prominent international position, particularly thanks to its role as a producer of popular fiction, but it shared the lead with France - which played a highly central role in most cultural fields (Janssen, Kuipers \& Verboord, 2008), including literature. Since then, the U.S. has acquired an increasingly central position in the international literary arena, concomitantly with the growing supremacy of the English language and American culture. In contrast, France has come to occupy a less dominant position than before (Sapiro, 2008), although it has remained the main center for West- and North-African writers as well as for francophone authors in Belgium, Switzerland, and Canada (Casanova, 2004). Germany has been unable to (re)gain a central literary position after World War II outside the German-speaking region, while the Netherlands traditionally occupies a (semi)peripheral position (Janssen, 2009).

In view of the above, Dutch and German newspapers will likely devote the most attention to foreign authors of non-western origin, i.e., those based in more central countries, and U.S. papers the least; French papers will probably take an in between position.

Table 2: Geo-Linguistic Ties of France, Germany, Netherlands, and the United States to Non-Western Countries

\begin{tabular}{|c|c|c|c|}
\hline & Colonial Ties & Language Ties & Labor Immigration Ties \\
\hline \multirow[t]{2}{*}{ France } & Morocco, Algeria, Tunisia & Morocco, Algeria, Tunisia & Morocco, Algeria, Tunisia \\
\hline & $\begin{array}{l}\text { Senegal, Gambia, Niger, } \\
\text { Mali, Guinea, Ivory Coast, } \\
\text { Burkina Faso, Benin, } \\
\text { Gabon, Republic of Congo, } \\
\text { Central African Republic, }\end{array}$ & $\begin{array}{l}\text { Senegal, Gambia, Niger, Mali, } \\
\text { Guinea, Ivory Coast, Burkina } \\
\text { Faso, Benin, Gabon, Republic of } \\
\text { Congo, Central African Republic, } \\
\text { Chad }\end{array}$ & $\begin{array}{l}\text { Senegal, Gambia, Niger, Mali, } \\
\text { Guinea, Ivory Coast, Burkina } \\
\text { Faso, Benin, Gabon, Republic of } \\
\text { Congo, Central African Republic, } \\
\text { Chad }\end{array}$ \\
\hline
\end{tabular}

French Caribbean*

Vietnam, Laos, Cambodia

\begin{tabular}{|c|c|c|c|}
\hline Germany & & & Turkey \\
\hline Netherlands & $\begin{array}{l}\text { Surinam, Dutch Antilles, } \\
\text { Indonesia }\end{array}$ & Surinam, Dutch Antilles & Turkey, Morocco \\
\hline U.S. & Philippines & $\begin{array}{l}\text { Former British Colonies (e.g., } \\
\text { Ghana, Nigeria, India) }\end{array}$ & Mexico \\
\hline
\end{tabular}

*excluding the French Overseas Departments and Territories 


\section{Geo-Linguistic Ties}

Studies of cultural globalization and foreign news production generally find geographic proximity and language kinship to be important predictors of the receptiveness to foreign products or events (Clausen, 2003; La Palestina \& Straubhaar, 2005). The stronger a country's "geo-linguistic ties" with particular non-western countries (Table 2), the more attention authors with that particular non-western background will probably receive. France has been the center of one of the largest colonial empires. In many French colonies, French was the official language and has kept its importance even after their independence (Crystal 1997). The Dutch colonial empire was much smaller and although Dutch is still the official language of Surinam and the Dutch Antilles, the Netherlands has never been the center of an international community of Dutch language nations.

France, Germany and the Netherlands hardly have ties with non-western countries solely based on language. The United States shares its language with many former British colonies. More importantly, since 1945, English has replaced other languages - primarily French - as the dominant and second language in many parts of the world (Crystal, 1997). Finally, the U.S. has close ties to other Anglophone countries, in particular the United Kingdom, Canada and Australia, which are all important recipients of non-western immigrants.

Third, all countries have labor immigration ties to other countries. After 1945, most Western-European countries recruited large numbers of workers from abroad, initially from nearby Mediterranean countries (e.g. Italy, Spain and Greece) but later also from more geographically and culturally distant nations. France recruited its guest workers mainly recruited from former (francophone) African colonies (Fetzer, 2000), while in Germany and the Netherlands, most immigrants came from linguistically distant countries, i.e., Turkey and Morocco (Lucassen \& Penninx, 1996; Martin, 1998). In the United States, most labor immigrants originate in Mexico, having Spanish as their mother tongue (Portes \& Rumbaut, 1996).

The countries' geo-linguistic ties with non-western nations suggest that French and Dutch newspapers devote the most attention to foreign authors with a non-western background, focusing on francophone and Dutch-language writers from former colonies. U.S. and particularly German newspapers will probably cover less foreign non-western authors, focusing respectively on anglophone writers and no group of authors in particular.

\section{DATA AND METHODS}

\section{Content Analysis}

We include France, Germany, the Netherlands, and the United States in this study to ensure sufficient comparability (i.e., all are modern western welfare states), while leaving enough differentiation on several relevant dimensions, i.e., ethnic diversity, colonial and immigration history, and position in the literary world-system.

For each country, we content analyzed two leading, elite oriented newspapers (one for the U.S.): Le Monde, Le Figaro (France), Frankfurter Allgemeine Zeitung, Süddeutsche Zeitung (Germany), NRC Handelsblad, de Volkskrant (Netherlands) and the New York Times (U.S.).

For each newspaper, we analyzed the coverage given to literature in 1955, 1975, 1995, and 2005. We used the constructed week sampling technique (see Janssen, Kuipers \& Verboord, 2008) to pick 24 editions of each paper per reference year (28 for the New York Times). We selected all articles (reviews, interviews, etcetera) focusing on a specific literary author or group of authors (not necessarily one book) for the present analysis $(\mathrm{N}=2,300)$. 


\section{Operationalization of Nationality, Ethnic Origin, and Geo-Linguistic Ties}

As we compare two types of authors (domestic and foreign), we first coded writers for "nationality." Whenever the country of citizenship was not known, we used the writer's country of origin according to literary reference works.

Second, for reasons of cross-national comparability and conceptual clarity, we classified and included authors using a meta-category: "authors of non-western ethnic origin." We consider ethnicity a social construction made up "out of the material of language, religion, culture appearance, ancestry or regionality (Nagel, 1994, p. 153).” Thus, we operationalized "non-western ethnic origin" along the lines of regional descent, or more specifically, we broadly included those regions that culturally have not been dominated by the Judeo-Christian tradition and subsequent secularization (Inglehart, 1997; Therborn, 1995), and that have a majority language which is not part of the Indo-European family. As such, our analysis includes authors whose origins can be traced back to Africa, Asia (including Turkey) and Central and South America. Since African Americans and Native Americans are considered ethnic minorities - albeit not non-western anymore - we included them in this study. Thus, the meta-category "literary authors of non-western origin" includes domestic ethnic minority authors (e.g., Abdelkader Benali, a Dutch national of Moroccan origin, discussed in De Volkskrant), foreign ethnic minority authors (e.g., Salman Rushdie, a British national of Indian descent, covered in the New York Times) and non-western majority authors (e.g., Orhan Pamuk, a Turkish national of Turkish descent, discussed in the Süddeutsche Zeitung).

Third, we operationalized geo-linguistic ties by coding the writers' countries or regions of origin as being (former) colonies and/or labor recruitment countries according to the data in Table 2. In addition, we determined the (predominant) language of each author's writings and whether he or she lived in the country of the newspaper at the time the article appeared.

\section{FINDINGS}

\section{Extent of Coverage of Authors of Non-Western Origin}

Out of the 2,300 articles devoted to literature, 172 focused on authors of non-western ethnic origin: 33 domestic and 139 foreign writers, including 33 - primarily American and English ethnic minority authors and 106 non-western majority authors. The amount of ethnic diversity - i.e., the number of authors of non-western descent as a percentage of all authors covered increases from 0-2\% in 1955 to 7-13\% in 1995, showing stability in 2005 (Table 3). Quite surprisingly, we find a similar longitudinal pattern in all four countries. Cross-national differences in the overall newspaper attention to ethnic diversity seem negligible.

\section{Domestic Authors}

In all four countries, newspaper attention to ethnic minority authors is limited (Table 3), which makes it difficult to draw conclusions about longitudinal developments. Most surprising is the near absence of ethnic minority authors in the French newspapers, despite their considerable population share and linguistic proximity. The German newspapers also cover hardly any ethnic minority authors. Neither the Dutch papers nor the New York Times (NYT) review any ethnic minority authors in 1955. While this is not very surprising considering the share of ethnic minorities in the Dutch population (1.2\%), ethnic minorities (primarily African-Americans) represented already $10 \%$ of the U.S. population in 1955. In 2005, ethnic minorities account for over $10 \%$ of the Dutch population, but ethnic minority authors take up only $5 \%$ of the literary coverage. In the U.S., ethnic minority authors' share has risen to $11 \%$, but this percentage is well behind ethnic minorities' share (33\%) in the population. ${ }^{7}$

\footnotetext{
${ }^{7}$ But whereas the increase in newspaper attention between 1955 and 1995 is primarily the result of a rise in the coverage of African American authors, the small increase in 2005 can be attributed to increased attention to first, second and third generation immigrant authors.
} 
Table 3: Amount of Non-Western Authors Discussed in Newspapers (Total, Domestic and Foreign) by Country and Year

\begin{tabular}{llllll}
\hline & & 1955 & 1975 & 1995 & 2005 \\
\hline France & Total & $\mathbf{2 \%}$ & $\mathbf{4 \%}$ & $\mathbf{1 3 \%}$ & $\mathbf{1 1 \%}$ \\
\hline & Domestic Ethnic Minorities & $0 \%(0)$ & $0 \%(0)$ & $2.4 \%(3)$ & $1.0 \%(1)$ \\
& Foreign & $8.3 \%(1)$ & $9.1 \%(5)$ & $24.8 \%(27)$ & $18.1 \%(25)$ \\
& - ethnic minorities & $(0)$ & $(1)$ & $(4)$ & $(1)$ \\
& - non-western majorities & $(1)$ & $(4)$ & $(23)$ & $(24)$ \\
\hline Germany & Total & $\mathbf{0 \%}$ & $\mathbf{2 \%}$ & $\mathbf{7 \%}$ & $\mathbf{8 \%}$ \\
\hline & Domestic Ethnic Minorities & $0 \%(0)$ & $0 \%(0)$ & $0 \%(0)$ & $1.4 \%(1)$ \\
& Foreign & $0 \%(0)$ & $3.9 \%(3)$ & $12.1 \%(15)$ & $12.1 \%(15)$ \\
& - ethnic minorities & $(0)$ & $(1)$ & $(4)$ & $(4)$ \\
\hline Netherlands & - non-western majorities & $(0)$ & $(2)$ & $(1)$ & $(11)$ \\
\hline & Total & $\mathbf{0 \%}$ & $\mathbf{6 \%}$ & $\mathbf{1 2 \%}$ & $\mathbf{9 \%}$ \\
\hline & Domestic Ethnic Minorities & $0 \%(0)$ & $3.2 \%(1)$ & $3.1 \%(2)$ & $5.1 \%(5)$ \\
& Foreign & $0 \%(0)$ & $6.8 \%(4)$ & $18.4 \%(19)$ & $12.5 \%(15)$ \\
& - ethnic minorities & $(0)$ & $(0)$ & $(9)$ & $(6)$ \\
& - non-western majorities & $(0)$ & $(4)$ & $(10)$ & $(9)$ \\
\hline US & Total & $\mathbf{1 \%}$ & $\mathbf{3 \%}$ & $\mathbf{1 1 \%}$ & $\mathbf{1 1 \%}$ \\
\hline & Domestic Ethnic Minorities & $0 \%(0)$ & $4.2 \%(3)$ & $9.3 \%(8)$ & $10.8 \%(9)$ \\
& - excl. African and Native Americans & $(0)$ & $(0)$ & $(3)$ & $(6)$ \\
& Foreign & $1.6 \%(1)$ & $0 \%(0)$ & $13.2 \%(5)$ & $10.5 \%(4)$ \\
& - ethnic minorities & $(1)$ & $(0)$ & $(0)$ & $(2)$ \\
& - non-western majorities & $(0)$ & $(0)$ & $(5)$ & $(2)$ \\
\hline
\end{tabular}

Total gives percentage of total author sample; domestic is percentage of total domestic authors; foreign is percentage of total foreign authors

\section{Foreign Authors}

Between 1955 and 1995, the share of non-western foreign authors has increased in all four countries (Table 3), showing stability (Germany) or decline (France, the Netherlands and the United States) in 2005. However, the overtime differences are only significant for France. Between 1975 and 1995, the share of non-western foreign authors also shows a significant rise in the German and Dutch newspapers. These trend data are in line with the development of newspaper coverage accorded to foreign authors in general (Janssen, 2009).

Whereas cross-national differences are salient when studying all foreign authors (Janssen, 2009), the extent of newspaper coverage given to authors of foreign non-western origin does not show such strong variations. This is probably due to the limited number of non-western authors. Only for 1995, we may conclude that French newspapers pay more attention to foreign authors of non-western descent than their German counterparts. Finally, articles discussing non-western majority authors - as compared to foreign ethnic minority authors - account for most of the coverage given to foreign non-western authors (Table 3). The details will be discussed below.

\section{Qualifying the Coverage of Authors of Non-Western Origin}

Table 4 shows to what extent authors of non-western ethnic origin are related to the four countries and how these ties can be characterized.

\section{Domestic Authors}

The coverage of ethnic minority authors remains relatively limited in all four countries. Most authors who do receive newspaper attention are linked to the country by language (Table 4) and they are also well-educated (see below). This finding underlines the importance of "linguistic" and "cultural” capital to writers' careers.

All four ethnic minority writers covered in French newspapers write in French and two of them also have a colonial tie: Rafael Confiant (Martinique) and Gisèle Pineau (Guadeloupe). Except for Francoise Chandernagor, they also studied at French universities. Despite their proficiency in French, our sample did not contain any author from a labor 
immigrant country. But considering the general educational level - and subsequent lack of cultural capital - we anticipated that aspirant-writers from these ethnic groups are less likely to meet the French literary field's strict entry requirements.

Table 4: Ties between Country of Newspaper and Covered Authors with a Non-Western Ethnicity (Domestic and Foreign), 1955-2005 (N=172)

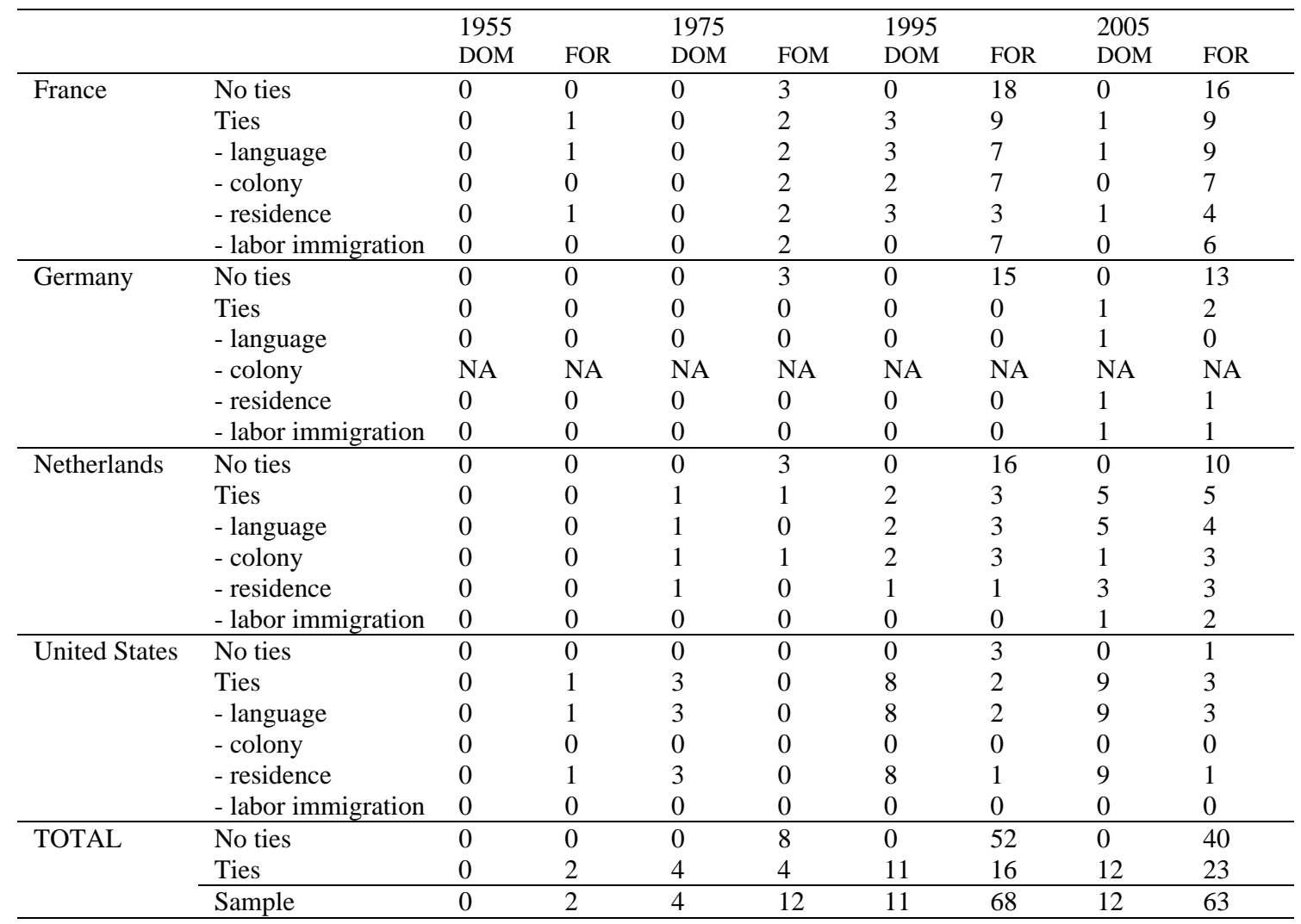

All figures are absolute numbers. Grey areas indicate itemization of ties in subcategories; contrary to main categories, these may double because authors may have several ties. DOM= Domestic; FOR=Foreign.NA=Not Applicable.

Despite the presence of quite a few Turkish minority authors (Rösch, 2006), German elite newspapers also hardly cover these authors, whose parents came to Germany as immigrant laborers; Imran Ayata being the only exception. This lack of coverage corresponds to the limited attention to ethnic diversity in the German literary field. However, it should be noted that many Turkish minority authors (initially) wrote in Turkish and had their books published by Turkish minority publishers (Rösch, 2006).

Half of the ethnic minority authors covered in Dutch newspapers are first or second generation immigrants from former colonies, who studied at Dutch higher education institutions: Yvonne Keuls (1975) and Rogier Boon (1995), both of Indonesian descent, and Antoine de Kom (1995) and Tessa Leuwsha (2005), both of Surinamese origin. Abdelkader Benali (Morocco) has been the only first or second generation labor immigrant discussed in our Dutch newspaper samples. In view of their higher Dutch language skills and level of educational attainment, it is not surprising that authors linked to former colonies are covered earlier and receive more coverage than (the descendants of) Turkish and Moroccan labor immigrants. Dutch newspapers also devote increasing attention to ethnic minority authors of non-related regions (China and Egypt), which accords with the greater receptiveness to ethnic diversity in the Dutch literary field. 
In the U.S. case, Mexican-Americans are the only ethnic group not represented in our newspaper sample, which may be also due to their relatively low level of (English) language proficiency and level of education. From 1975 onwards, the NYT discusses - well-educated African-American authors (e.g., Gil Scott-Heron, Shirlee Taylor Haizlip, Gloria WadeGayles), followed by Asian-American writers in 1995 (e.g., Amy Tan, Jin Ha) and a NativeAmerican author in 2005 (Louise Erdrich). This development corresponds to the opening up of the American literary canon since in the early 1990s. But whereas the share of ethnic minority authors in literary anthologies rises to $30 \%$, their representation in newspaper coverage remains far more limited (Berkers, 2009b).

\section{Foreign Authors}

Geo-linguistic ties appear more important for the French newspapers than for their German, Dutch, and American counterparts. From 1975 onwards, around 40\% of non-western foreign authors are linked to France by language, colonial past, residence, and/or labor immigration. The majority consists of francophone authors who reside in France, but who were born in and are still citizens of - former colonies. Newspaper critics and other agents in the French literary field may have long considered writers from its former colonies as "too similar to be celebrated as exotic foreigners but too remote to be considered worthy of interest" (Casanova, 2004, p. 122), but they seem to have embraced these authors - instead of English-language American and British ethnic minority authors - once France came to occupy a less central position in the literary world system. ${ }^{8}$

Germany has no colonial past and it has only one major resource country for labor immigrants (Turkey). This more or less explains why only two out of 33 authors in our sample have ties to Germany: Fadhil Al-Azzawi, a Berlin-based writer of Iraqi origin and 2006 Nobel Prize winner Orhan Pamuk. Pamuk's presence in German newspapers should in all likelihood be attributed to his international literary reputation rather than the GermanTurkish labor immigration connection. German and Dutch papers in particular cover a significant number of these non-western, "star authors" ${ }^{9}$ who were first "discovered" in major one of the major international centers, which seems to underline the semi-peripheral position of the Germany and the Netherlands in the literary world-system.

As expected (Table 2), Dutch newspaper coverage to authors from former colonies is less extensive than in France. In 1975, one article (out of four) deals with authors of Surinamese and Antillean origin in general. The 1995 and 2005 newspaper articles feature two Antillean authors (Frank Martinus Arion and Richard Piternella) and four Surinamese writers (Albert Helman, Clark Accord, Roue Hupsel, and Trefossa). Except for the latter, these authors are Dutch-language writers, who in most cases reside(d) in their region of origin. Foreign authors originating in labor sending countries also receive minimal coverage. Many foreign authors with no direct ties to Netherlands are British and American ethic minority authors (e.g., Salman Rushdie, Hanif Kureishi, Timothy Mo). This not only underlines the peripheral position of the Dutch literary field, but also its Anglo-Saxon orientation.

In the U.S. case, the labor immigration tie is also absent as the NYT covered no Mexican authors. The small number of non-western foreign authors in the NYT accords with America's central position in the literary world system. Moreover, these authors all reside in other Anglophone countries - e.g., Aubrey Menen, Kazuo Ishiguro (U.K.) and Browyn Bancroft (Australia) - or in the U.S. itself - such as Anita Desai (India) and Chris Abani (Nigeria). Compared to the non-western authors based in France, the origins of these U.S. based authors are far more diverse, again pointing to America's central role in the literary

\footnotetext{
${ }^{8}$ Our findings confirm the declining centrality of France. First, although Paris still appears to function as a center for francophone authors from its former colonies, only a few non-western authors from non-related regions reside in France and/or have written in French. Second, only few Paris-based, francophone authors of non-western origin received coverage in German, Dutch and American newspapers.

${ }^{9}$ Measuring international literary prestige using various indicators (e.g., sales figures, popular media attention) is beyond the scope of this study. We therefore looked "merely" at the number of times each author has been translated according to UNESCO's Index Translationum.
} 
world system. This central role is also reflected in the sizeable numbers of U.S. ethnic minority writers and U.S. based foreign authors who receive coverage in the French, German and Dutch newspapers.

\section{CONCLUSION}

The extent of newspaper coverage given to literary authors of non-western origin since 1955 shows a similar development for France, Germany, the Netherlands and the United States. First, the share of non-western authors within the total literary coverage increased, particularly between 1975 and 1995, pointing to a growing awareness in the West of the "rest." Second, in 2005, we find a backlash in newspaper attention to - in particular foreign authors of non-western descent. The coverage of all (western and non-western) foreign authors does not show such a general trend (Janssen, 2009). Could it be that the attention to ethnic diversity has reached a glass ceiling? Several scholars have noted a "retreat" from multiculturalism in various countries' policies (Bloemraad, Korteweg \& Yurdakul, 2008). So the decline in attention might be related to a change in the political climate of most countries, resulting in a stronger focus on the national majority literature.

The coverage of foreign authors of non-western origin shows some interesting albeit mostly not significant - cross-national differences. Concomitantly with the erosion of France's central position, French newspapers have become more interested in foreign nonwestern authors as have French publishers and cultural policy makers (Heilbron, 2008). This shift can partly be explained by France's geo-linguistic ties with its many former colonies, rendering France as the center of the Francophone literary world. But the significant increase of attention to non-western writers with no direct ties to France could indicate that the French discontent with globalization à l'américaine has promoted interest in "peripheral" foreign literatures (Sapiro, 2008). This would be in line with France's tradition as a great literary nation, and perhaps with a latent sense of its mission civilisatrice (Heilbron, 2008). In view of their respective positions in the literary world-system, it is hardly surprising that the Dutch and the German newspapers pay far more attention to foreign authors of non-western origin than the NYT.

As expected, newspaper coverage of ethnic minority authors is much more limited. The few ethnic minority writers who do receive attention generally have strong geo-linguistic ties with that particular country and are well-educated. This confirms the importance of linguistic and cultural capital for making a literary career. In addition, both the French and German literary fields do not seem very receptive to ethnic diversity. The virtual absence of ethnic minority writers in the French case is particularly intriguing and calls for further research, as these writers' alleged lack of writing skills and "marketability" provides a partial explanation at best. Dutch literary institutions as well as newspapers seem to have become more open to ethnic minority authors. However, probably due to lower language skills, labor immigrant minorities and their descendants lag behind authors from former colonies. Finally, in line with the larger number and greater receptiveness to ethnic minority authors in the American literary field, our NYT sample counts more ethnic minority authors than all European newspaper editions combined.

Although the coverage of non-western majority authors suggests that narrowlydefined cultural globalization - the diffusion of cultural artifacts from the "rest" to the West is (still?) responsible for most ethnic diversity, the impact of international migration has increased in importance. Except for the U.S., its direct effect on each national literary field has been limited. But the increased presence of American ethnic minority authors in Dutch and German papers, suggests that the impact of international migration is mediated by a country's position in the literary world-system. As a result of their successful mobilization, these authors could gain increasing recognition in the U.S., culminating in their inclusion in university curricula and the ranks of prestigious literary prizewinners. With the U.S.'s growing centrality in the literary world-system and the increasing dominance of the English language, authors like Toni Morrison and even non-star authors like Edwidge Danticat and Suki Kim could also gain international literary prestige. In contrast, for Dutch or German 
ethnic minority writers, chances of an international breakthrough remain limited, being based outside one of the anglophone centers of the literary world system and not writing in a hypercentral language.

\section{REFERENCES}

Berkers, P. (2009a). Ethnic boundaries in American, Dutch and German national literary policies, 1965-2005. International Journal of Cultural Policy, 15, 33-50.

Berkers, P. (2009b). Ethnic boundaries in national literary histories. Poetics, 35, 419-438.

Bloemraad, I., Korteweg, A. \& Yurdakul, G. (2008). Citizenship and immigration. Annual Review of Sociology, 34, 153-179.

Bourdieu, P. (1993). The field of cultural production. Cambridge,UK: Polity Press.

Bryson, B. (2005). Making multiculturalism. Stanford, CA: Stanford University Press.

Carliner, G. (1999). The language ability of U.S. immigrants. International Migration Review, 34, 158-182.

Casanova, P. (2004). The world republic of letters. Cambridge, MA: Harvard University Press.

Centraal Bureau voor de Statistiek. (2008). http://statline.cbs.nl.

Clausen, L. (2003). Global news production. Copenhagen: Copenhagen Business School Press.

Corse, S.M. \& Griffin, M.D. (1997). Cultural valorization and African American literary history. Sociological Forum, 12, 173-203.

Crane, D. (2002). Culture and globalization. In D. Crane, N. Kawashima \& K. Kawasaki (Eds.), Global culture (pp. 1-28). London: Routledge.

Crystal, D. (1997). English as a global language. Cambridge: Cambridge University Press.

Duell, J. (2000). Assessing the literary. In M. Lamont \& L. Thévenot (Eds.), Rethinking comparative cultural sociology (pp. 94-124). Cambridge, UK: Cambridge University Press.

Dustmann, C. (1994). Speaking fluency, writing fluency and earnings of migrants. Journal of Population Economics, 7, 133-156.

Fetzer, J.S. (2000). Public attitudes toward immigration in the United States, France, and Germany. Cambridge, UK: Cambridge University Press.

Fetzer, J.S. \& Soper, J.C. (2005). Muslims and the state in Britain, France, and Germany. Cambridge, UK: Cambridge University Press.

Ferree, M.M., Gamson, M.A., Gerhards, J. \& Rucht, D. (2002). Shaping abortion discourse. Cambridge, UK: Cambridge University Press.

Fiss, P.C. \& Hirsch, P.M. (2005). The discourse of globalization. American Sociological Review, 70, 29-52.

Griswold, W. 1987. The fabrication of meaning. American Journal of Sociology, 92, 10771117.

Guillén, M. (2001). Is globalization civilizing, destructive or feeble? Annual Review of Sociology. 27, 235-260.

Hargittai, E. \& Centeno, M.A. (2001). Introduction: Defining a global geography. American Behavioral Scientist, 44, 1545-1560.

Hargreaves, A.G. (1995). Immigration, "race" and ethnicity in contemporary France. New York: Routledge.

Heilbron, J. (1999). Towards a sociology of translation. European Journal of Social Theory, 2, 429-444.

Heilbron, J. (2008). Responding to globalization. In A. Pym, M. Shlesinger \& D. Simeoni (Eds.), Beyond Descriptive Translation Studies (pp. 187-197). Amsterdam: John Benjamins.

Held, D., McGrew, A., Goldblatt, D. \& Perraton, J. (1999). Global transformations.

Cambridge, UK: Polity Press.

Huggan, G. (2001). The post-colonial exotic. London: Routledge. 
Inglehart, R. (1997). Modernization and postmodernization. Princeton, NJ: Princeton University Press.

INSEE (Institut National de la Statistique et des Études Économiques). (1999). Population Census. Paris: INSEE.

Jankowsky, K. (1997). German literature contested. The German Quarterly, 70, 261-276.

Janssen, S. (1997). Reviewing as social practice. Poetics, 24, 275-297.

Janssen, S. (2009). Foreign literatures in national media. Arcadia: International Journal for Literary Studies, 44, 352-375.

Janssen, S. Kuipers, G. \& Verboord, M. (2008). Cultural globalization and arts journalism. American Sociological Review, 73, 719-740.

Joosten, J. (2005). Waar zou Spits op doelen? [Reaction to Spits’ plea for a Western canon] Trouw, July 23, 2005, L01.

Kaufman, J. \& Patterson, O. (2005). Cross-national cultural diffusion. American Sociological Review, 70, 82-110.

Kraidy, M.M. (2002). Hybridity in cultural globalization. Communication Theory, 3, 316-339.

La Palestina, A.C. \& Straubhaar, J.D. (2005). Multiple proximities between television genres and audiences. Gazette. 67, 271-288.

Lay-Chenchabi, K. (2004). Breaking the silence. Contemporary French and Francophone Studies, 10, 97-104.

Lizardo, O. (2008). Understanding the flow of symbolic goods in the global cultural economy. International Journal of Contemporary Sociology, 45, 13-34.

Lucassen, J. \& Penninx, R. (1996). Nieuwkomers, nakomelingen, Nederlanders [Newcomers, descendants, Dutch men]. Amsterdam: Het Spinhuis.

Malingret, L. (2002). Stratégies de traduction [Strategies of translation]. Arras: Artois Presses Universite.

Martin, P.M. (1998). Germany: Reluctant land of immigration. Washington, D.C: American Institute for Contemporary German Studies (AICGS).

Nagel, J. (1994). Constructing ethnicity. Social Problems, 41, 152-176.

Obbema, F. (2003). Allochtoon verkoopt niet [Ethnic minority writers do not sell]. DeVolkskrant, March 3, 2003.

Portes, A. \& Rumbaut, R. (1996). Immigrant America. Berkeley, CA: University of California Press.

Rösch, H. (2006). Kurzporträts und veröffentlichung von und zu autorinnen der Deutschsprachigen migrationsliteratur [Portrayals and publications of female writers of the German-language migrants literature]. www2.tu berlin.de/fak1/el/board.cgi?id=fadi\&action=download\&gul=36

Sapiro, G. (Ed.). (2008). Translatio: Le marché de la traduction en France à l'heure de la mondialisation [Translatio: The translation market in France in the era of globalization]. Paris: CNRS Editions.

Shoemaker, P.A. \& Reese, S.D. (1996). Mediating the message. White Plains, NY: Longman.

Statistisches Bundesamt. (2002, 2003, 2006). Bevölkerung und Erwerbstätigkeit [Population and employment]. Statistisches Bundesamt.

Tesser, P., Merens, J. \&. van Praag, C. (1999). Rapportage minderheden 1999 [Minorities monitor 1999]. The Hague: SCP-The Netherlands Institute for Social Research.

Therborn, G. (1995). European modernity and beyond: the trajectory of European societies, 1945-2000. Thousand Oaks, CA: Sage.

T’Sjoen, Y. (Ed.) (2004). De zwaartekracht overwonnen: Dossier over “allochtone” literatuur [Overcoming gravity: A report on "ethnic minority” literature]. Gent: Academia Press.

U.S. Bureau of the Census. (1981, 2000). Summary Files.

U.S. Bureau of the Census. (2007). Statistical abstract of the United States. Washington, DC: Government Printing Office.

van Rees, K. (1983). How a literary work becomes a masterpiece. Poetics, 12, 397-417.

Worbs, S. (2003). The second generation in Germany. International Migration Review, 37, 1011-1038. 
Pauwke Berkers is an assistant professor at the Department of Arts and Culture Studies at Erasmus University Rotterdam. His works addresses how institutions in the literary field (e.g., textbooks, policy, and journalistic criticism) deal with increasing ethnic diversity in various Western countries.

Susanne Janssen is Professor of Sociology of Media and Culture and Head of the Department of Media and Communication at Erasmus University Rotterdam. Her research focuses on the agents and institutions involved in the creation, dissemination and valuation of literature and other art forms, and the social and institutional conditions under which cultural artifacts are produced and received.

Marc Verboord is Assistant Professor in the Department of Media and Communication at Erasmus University Rotterdam. He has published on trends in the reading of fiction books, cultural omnivorousness, media socialization and cultural globalization. His current research activities include the comparative study of cultural classification systems and the study of the implications of the Internet for the cultural field 